\title{
Efficiency Estimation for Activities for Multi-Industry Holdings as Forms of Business Associations
}

Beloborodova A.L.

Kazan Federal University, Institute of Management, Economics and Finance, Kazan, 420008, Russia

a-beloborodova@mail.ru

\section{Doi:10.5901/mjss.2015.v6n1s3p491}

\begin{abstract}
The article analyses the methods for the efficiency estimation for holding structures in general and multi-industry holdings in particular available in the research literature. The necessity to develop the methods enabling to perform the estimation of efficiency of activities for multi-industry holdings within the stakeholder theory has been proved. A range of indices describing the efficiency of activities of multi-industry holdings from a perspective of meeting interests of certain stakeholders has been proposed. The methods for the estimation of efficiency of activities of multi-industry holdings within the stakeholder theory has been developed.
\end{abstract}

Keywords: Multi-industry holdings, business associations, management, stakeholder theory, estimation of efficiency.

\section{Introduction}

Acceleration of globalization processes results in the increased competition in the domestic market and in the external market, and the competitiveness becomes a governing factor for the economy growth of a country. In order to implement the positive effect of the globalization, the relevant institutional structures are necessary, firstly, business associations that, as a rule, are the economy drivers for the economy of any country. At present, holdings are considered the most demanded forms of the business association in Russia, and inefficiency of their activities precludes the growth of the country's economy [8]. Within the framework of this article, special attention will be paid to activities of multi-industry holdings as the most complex form of corporate associations.

Due to the above, the matter of developing a management system for the activities of multi-industry holdings based on the estimation of their economic efficiency becomes essential [4].

\section{Theory}

In spite of the fact that a wide range of works of domestic and foreign scientists has been published during the recent years on the matter of estimation of efficiency of activities if holding structures, there is a range of unexplored theoretical and methodical issues. The majority of methods reduce themselves to the development of a system of qualitative indices describing various aspects of holdings' activities unrelated to the subjects of the estimation. In the course of its activities, the holding interacts with various subjects, and for each of them, the efficiency of their activities is described as meeting certain interests [1]. Therefore, the development of the methods for estimating the efficiency of activities of multi-industry holding where the extent of the meeting of interests of certain stakeholders is taken into account becomes an indispensable instrument for the strategic and operative management of the holdings [11].

\section{Method}

As a multi-industry holding is a form of a business association, the efficiency of its activities depends of the efficiency of separate business structures being its parts. Therefore, the methods we have developed enables to represent the position of each enterprise in the activities of the multi-industry holding in the perspective of satisfying the stakeholder by them [5]. Figure 1 represents the stages for the estimation of activities of the multi-industry holdings within the stakeholder theory.

Further, each stage will be described in more detail. The stakeholder theory came into being for the first time in 1984 due to the release of the book "Strategic Management: A Stakeholder Approach" by Edward Freeman where the 
author suggests that a firm should be regarded in the perspective of its interaction with the inner and outer environment, and the interests and demands of the environment should be considered by the management in the course of making managerial decisions[7].

1. Selection of the parties interested in the efficiency of activities of the multi-industry holding

$\begin{aligned} & \text { 2. Shaping of the array of indices describing the efficiency of activities of the enterprises within the } \\
& \text { multi-industry holding for each of the stakeholders }\end{aligned}$
\begin{tabular}{|l|l|} 
3.1. Calculation of the rating estimation for \\
each of the enterprises of the multi- \\
industry holding (Rj)
\end{tabular}
$\begin{aligned} & \text { 4.2. Calculation of the share of the added value } \\
& \text { introduced by each of the enterprises within the } \\
& \text { multi-industry holding as a result of their activities } \\
& \text { (AVSi) }\end{aligned}$
5. Selection of the development strategy for each of the enterprises of the multi-industry holding
estimate the efficiency of activities for the stakeholders

Fig. 1 Stages of efficiency estimation for the activities of multi-industry holdings within the stakeholder theory

Edward Freeman defines a "stakeholder" as all the corporate or private persons entering into contact with the organization in the process of its activities. Such treatment of the term is considered theoretical as in practice there is hardly an entity that can take the interests or demands of representatives of the internal and external environment into account [3]. Therefore, the most authors being the followers of the E. Freeman's theory suggest that only the interests and demands of the parties that are in position to actually affect the welfare of the entity should be taken into account. For each entity, depending on the area of its activities, its size, legal status etc., the list of the stakeholders is different. Thus, the activities of the multi-industry holdings depend, most of all, on the following stakeholders: shareholders, managers, employees of the enterprises, the state represented by bodies of legislative and executive power, creditors (investors), purchasers, suppliers and contractors [6].

As a result of investing funds into the initial capital of the holding, shareholders receive annual income aggregated as the alteration of the stock pricing and the accrued dividends. The level of the total return index does not evidence a satisfaction of the shareholders' interests, and in the framework of the original methods we will consider the growth rate of such index during a period $\left(X_{1}\right)$.

Interacting with enterprises of the holding, representatives of the "employees" group are interested in obtaining both material and moral benefits. At present, the material benefits are predominant for Russian employees when selecting a job [10]. The level of profits itself does not evidence a satisfaction of their interests. As a part of the original methods, we will consider the growth rate of such index during a period $\left(X_{2}\right)$.

When interacting with enterprises of a multi-industry holding, the state satisfies the following interests:

1. Replenishment of the income part of the budget by means of annual growth of the tax payments. The growth rate of this index will be considered $\left(X_{3}\right)$.

2. Securing of the people's occupation by means of annual growth in numbers of the employees engaged by the enterprises of the multi-industry holding $\left(X_{4}\right)$.

3. Increase of the production volume generated by the enterprises of the multi-industry holding $\left(X_{5}\right)$.

Interacting with enterprises of the holding, representatives of the "consumers" group are committed to satisfy their interest in purchasing high-quality goods at affordable prices and with a proper service level. It is not possible to estimate the satisfaction of the consumers' interests by means of a survey because, as a rule, multi-industry holding comprise more than tens of enterprises engaged in various areas of the economy [9]. Therefore, in the framework of the proposed methods, we will use are more unified index, that is sales revenue in comparable prices. It is assumed that the satisfaction of the consumers' interests will result in the growth of the consumption volume $\left(X_{6}\right)$.

The "suppliers and contractors" group, while interacting with enterprises of the holding, pursue certain interests whose range may vary depending on the area where the enterprise is engaged etc. However, such interests as provision by the enterprises of the holding of continuous orders for large volumes of supplied goods and timely payments for the supplies are important criteria for the satisfaction of interests of any supplier. As the continuity and volumes of supplies 
depend of the sales volumes by the holding's enterprises themselves, in this case it is proper to consider the growth rate of the sales revenue in comparable prices $\left(X_{6}\right)$. The continuity and timeliness of the payments are represented by the following indices: growth rate for the accounts payable ratio $\left(X_{7}\right)$, and the growth rate for the absolute liquidity ratio $\left(X_{8}\right)$.

The "creditor" group is interested, first of all, in the timely and complete return of loaned means. The enterprise is in position to satisfy such interests provided it is in a good financial standing. The following indices have been defined in the course of survey of credit departments of leading banks in the Republic of Tatarstan: total debt to equity $\left(X_{9}\right)$, current assets coverage ratio $\left(X_{10}\right)$, liquid ratio $\left(X_{11}\right)$, assets turnover ratio $\left(X_{12}\right)$, and return on equity $\left(X_{13}\right)$. The increase of such indices evidences the solvency and financial health of the enterprise.

In order to calculate the ranking estimation, we adopted the method by N.E. Zimin as it is the method that, according to the author, can be applied in inter-industry comparisons [2]. The ranking estimation within such method is calculated independently for each of the enterprises:

$R j=\sqrt{(1-X 1 j)^{2}+(1-X 2 j)^{2}+\ldots+(1-X n j)^{2}}(1)$

where

$X \mathrm{ij}$ - is normalized indices for the $\mathrm{j}$-th enterprise.

$X i j=a i j / \max a i j(2)$

where

aij - is an array where the lines (i) are names of the indices, and columns (j) are the names of the enterprises of the holding.

An enterprise with the least $R$ value will have the highest ranking.

After that, it is necessary to calculate the value of the AVS index:

$\mathrm{AVSj}=\mathrm{AVj} / \mathrm{\Sigma} \mathrm{AVj}$

where AVSj is the share of the added value generated by the $j$-th enterprise in the total added value generated by all the enterprises of the multi-industry holding, and AVj is the added value generated by the j-th enterprise.

Based on the indices calculated above, the array can be constructed where OX axis is the share of the added value generated by the $j$-the enterprise, and OY axis is the ranking estimation for the $j$-th enterprise describing the satisfaction of the interests of the stakeholders by such enterprise in the course of its activities (Fig.2).

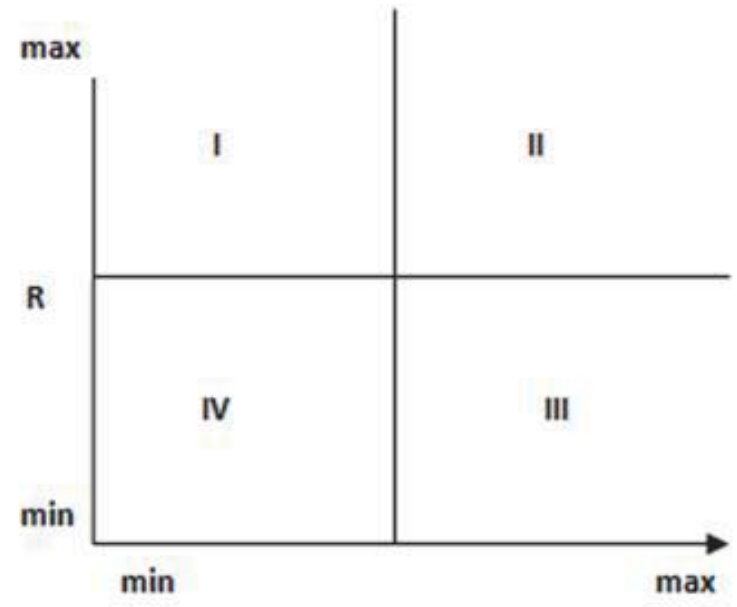

AVS

Fig. 2. Estimation array for the efficiency of activities of enterprises within the multi-industry holding as a part of the stakeholder theory

\section{Results}

The strategy for each of the enterprises of the multi-industry holding is defined depending on which square of the array (I, II, III or IV) it ends up in when constructing the array.

The enterprises in the square I are efficient for the holding but they contribute insignificantly in the generation of the total added value. The activities of such enterprises require minimum interference on the part of the management of the 
parent company of the holding.

The activities of the enterprises ending up in the square II are the most efficient for the multi-industry holding as they satisfy the stakeholders to the maximum and contribute the most to the generation of the added value by the holding. The top managers of the holding's parent company should supervise the activities of such entities as any slackening of such enterprises may considerably weaken the position of the holding in general.

The enterprises ending up in the square III are the most "weak link" of the multi-industry holding. Although they contribute significantly in the added value generated by the multi-industry holding, they are of poor efficiency in the perspective of satisfaction of the stakeholders. Therefore, they require the maximum supervision and interference on the part of the management of the parent company.

The enterprises ending up in the square IV are of no interest to the management of the holding as they are inefficient in the prospective of satisfaction of stakeholders and are the least contribute to the generation of the added value by the multi-industry holding. As a rule, if such enterprises are not strategic for the holding in the long-term prospective, it is advisable to withdraw such enterprises from the holding's structure.

\section{Conclusions}

Thus, multi-industry holdings are the driver of the Russian economy, and the welfare of the country depend on the efficiency of their operations. Being a kind of a "public" structure, in the course of their activities multi-industry holders interact with great many stakeholders. Satisfaction of interests of six of them (shareholders, the state, purchasers, creditors, suppliers and contractors, employees) is crucial for a holding structure. Therefore, the method proposed by the author is an essential instrument to estimate the efficiency of activities of multi-industry holdings in the perspective of satisfaction of stakeholders' intersts.

\section{References}

AntonchenkoN.G., Kalenskaya N.V. Developing a Methodology for Assessing the Efficacy of Managerial Decisions in Entrepreneurial Establishments (2014) Life Science Journal 11(7s). pp. 365-369.

Barakat, S., Boddington, M., Vyakarnam, S. Measuring entrepreneurial self-efficacy to understand the impact of creative activities for learning innovation // International Journal of Management Education 12 (3) , 2014. pp. 456-468.

Cabral, L. Good turnover and bad turnover: Barriers to Business and productivity // Economics Letters 125 (2), 2014. pp. 179-181.

Ghosal, V., Ye, Y. Uncertainty and the employment dynamics of small and large businesses // Small Business Ecjnjmics 40 (2) , 2014. pp. 555-578

Kalenskaya N.V., Akhmetshin R.M., Grigoryeva L.L. The Development of State Regulation in Small Entrepreneurship Infrastructure Provision // Mediterranean Journal of Social Sciences 18, 2014. pp. 27-33.

Kalenskaya N.V, Shafigullina A.V. The Invariance as a Feature of Business Systems' Infrastructural Innovative Development (2014) Mediterranean Journal of Social Sciences 18, pp. 241-247.

Novikova E., Beloborodova A. An Assessment of the Efficiency of the Information System of Design-and-survey Organizations Based on the Analysis of the Information Capacity of Projects Implemented (2014) World Applied Sciences Journal 29(1), pp. 20-25.

Ankudinov B., Lebedev O. V. Investment drivers of shareholder value creation in large publicly traded Russian companies // Investment Management and Financial Innovations. - 2014. - 11 (2) . - pp. 77-85.

Safiullin L.N., Ismagilova G.N., Safiullin N.Z., Bagautdinova N.G. The development of welfare theory in conditions of changes in the quality of goods and services (2012) World Applied Sciences Journal 18, pp. 144-149.

Sambharya, R., Musteen, M. Institutional environment and entrepreneurship: An empirical study across countries// Journal of International Entrepreneurship 12 (1) , 2014. pp. 43-66

Vagizova V.I., Lurie K.M., Ivasiv I.B. Clustering of Russian banks: business models of interaction of the banking sector and the real economy/ V.I. Vagizova, K.M. Lurie, I.B. Ivasiv// Problems and Perspectives in Management. - 2014. - №1., p. 72-82

Urbano, D., Alvarez, C. Institutional dimensions and entrepreneurial activity: An intenational study // Small Business Ecjnjmics 42 (4), 2014. pp. 703-716.

Valeeva J.S., Sharafutdinova N.S.,Kulkova V.Y., Quality management system's role in operation of retail trade networks (2014) Life Science Journal 11(5), pp. 555-558.

Ablaev I.M., Khovanskaya E.S. Essence and Economical Substance of Innovative Cluster in Territorially Localized Business System/l Mediterranean Journal of Social Sciences.- Vol.5, No12, (2014)-pp.159 - 162.

Klaas J., Vagizova V. Formation of sustainable development strategy of credit organizations based on Balanced Scorecard // Investment Management and Financial Innovations. - 2014. - № 1. c. 87-96. 